\title{
Analisis Jurnal
}

NIM $\quad: 672020032$

Nama : Bernadus Enggar Prasetya

\section{A. IDENTITAS JURNAL}

\section{Nama Jurnal : Jurnal Teologi Kristen}

2. Volume : 2 (dua)

3. Nomor : 1 (satu)

4. Halaman : 21

5. Tahun Penerbit : 2020

6. Judul Jurnal : Teologi Penghormatan : Dialog Kekristenan dengan Ritus Kembang Kuningan

7. Nama Penulis : Ayub Wajrianto, Fibry Jati Nugroho

\section{B. ISI JURNAL}

1. Masalah Penelitian :

Dialog antara kekristenan dengan Ritus Kembangkuningan (Ritual yang merupakan rangakaian ritual upacaara berdoa bagi leluhur)

2. Lokasi Penelitian :

Desa Polobogom Kecamatan Getasan, Kabupaten Semarang.

3. Metode Penelitian :

- Pendekatan Kualitatif dengan metode deskriptif-analisis digunakan untuk mendapatkan pemahaman yang lebih luas dan mendalam mengenai suatu peristiswa serta untuk menemukan makna di dalam suati peristiwa atau fenomena.

- Teologi Kontekstual dimana pengusaan metode untuk mengubah elemen elemen seperti (antropologi terjemahan, praksis, budaya tandingan dan sintesis.) dengan cara begitu dapat memiliki banyak data yang diperlukan.

4. Teori yang dipakai: -

5. Hasil Penelitian :

Ritual Kembang Kuningan merukapan sebuah bentuk penghormatan kepada leluhur. Kepercayaan yang timbul dikalangan masyarakat tradisonal,bahwa berdoa bagi leluhur maka leluhur juga akan mendoakan keturunannya yang masih ada di dunia supaya Tuhan akan mendoakan keturunannya yang masih ada di dunia supaya Tuhan 
memberikan segala kemurahannya yang masih ada di dunia supaya Tuhan memberikan segala kemurahannya.

Dalam tradisi gereja Pentakosta dan Kharismatik, orang yang sudah mengalami kematian, jiwa/rohnya kembali kepada Allah. Acara pemakaman untuk orang sudah mati tidak difokuskan kepada orang yang mati, tetapi kepada keluarga yang di tinggalkan. Fokusnya ditujukan untuk penghiburan dan pengutan iman.

Dilihat dari sisi konteks baik konteks lokak, Bliblikal dan tradisi gereja terlihat ada unsur kesamaan dari kekristenan dan ritus kembang kuningan, yaitu kematian manisa secara jasmani bukanlah akhir dari perjalanan kehidupan, masih ada perjalanan kehidupan yang selanjutnya. Persoalan berdoa kepada orang mati dan berkomunikasi dengannya, tradisi Katolik, Lutheran dan Konteks budaya menerimanya menjadi satu bagian doktrin yang yang di percayai. Sedangkan calvin, Pentakosta, Kharismatik dan Blibikal cenderung negatif dalam menyikapi doa terhadap orang mati.

\section{KELEBIHAN DAN KEKURANGAN}

1. Kelebihan:

Kita dapat mengetahui persepektif manusia terhadap tradisi ritual Kembang Kuningan.yang dimana berdoa untuk para leluhur. Dari situ kita tahu bagaimana kepercayaan agama dan kepercayaan terhadap tradisi tradisional dapat berjalan selaras atau saling tolak menolak. Dimana ada beberapa aliran kristen yang menerima ada juga yang tidak.

\section{Kekurangan:}

Dari mengetahui persepektifnya kepercayaan tradisional dan kepercayaan agama, dapat menimbulkan sebuah pemikiran yang terombang ambing jika manusianya sendiri tidak teguh pada iman yang ia percayai. 